\title{
FUZZY LOGIC MODELING OF THE OCULAR TEMPERATURE OF CATTLE IN THERMAL STRESS CONDITIONS
}

\author{
Ana C. de S. S. Lins ${ }^{1 *}$, Ingrid J. S. Souza ${ }^{1}$, Dian Lourençoni ${ }^{1}$, \\ Tadayuki Yanagi Júnior², Italo E. dos A. Santos ${ }^{1}$
}

${ }^{1 *}$ Corresponding author. Universidade Federal do Vale do São Francisco/ Juazeiro - BA, Brasil.

E-mail: ana_carolina_lins@hotmail.com | ORCID ID: https://orcid.org/0000-0002-9182-8625

\section{KEYWORDS}

thermal comfort, thermal imaging, beef cattle.

\begin{abstract}
This study proposes a fuzzy logic model capable of predicting the ocular temperature (OT) of beef cattle by means of infrared thermography. The goal of this study is to establish a methodology for making decisions related to animal welfare. The experiment was carried out at a commercial beef production farm, located in the south of Minas Gerais state, where twenty-eight Brahman cattle (Bos Taurus Indicus) raised in extensive production systems were evaluated. Thermal images of the entire head of the animal were collected in order to measure the ocular temperature (OT). Concurrently, the variables air dry bulb temperature (DBT) and relative humidity (RH) were recorded. The fuzzy logic model was developed using the Mandani inference method, based on the input variables DBT and RH and the output variable OT, and using the experimental data as reference. The proposed fuzzy logic system allows the estimation of the ocular temperature of beef cattle with an error of $1.71 \%$ and a coefficient of determination $\mathrm{R}^{2}$ of 0.8749 . These values validate the proposed fuzzy logic system for helping to make decisions for better animal welfare.
\end{abstract}

\section{INTRODUCTION}

Animal welfare is undoubtedly one of the most discussed topics in society, thereby increasing the pressure on beef production farms to raise animals considering their welfare. However, for evaluation and confirmation that the animals are in ideal conditions, invasive methods such as blood collection and rectal temperature measurement are used, which can cause stress to animals and consequently alter the evaluation results (Stewart et al., 2008, Bustos Mac-Lean, 2012).

Several authors have described non-invasive methods that can be used to obtain stress-free organism data; these methods can also be used to evaluate the conditions of thermal comfort and animal welfare (Fonsêca et al., 2014, Kokin et al., 2014, Maia et al., 2015, Gabriel Filho, et al., 2016, Milan et al., 2016, Borchers et al., 2017, Nascimento et al., 2017, Costa et al., 2018, Gorczyca et al. 2018). Among these methods is infrared thermography, already used by several authors (Moura et al., 2011, Bartolomé et al., 2013, George et al., 2014,
Church et al., 2014, Salles et al., 2016). It is noteworthy that the high cost of acquiring infrared equipment is still an obstacle for small and medium rural producers.

The physiological responses of animals are directly related to climatic factors, therefore, with this knowledge it is possible to improve the handling, nutrition, facilities, and equipment, to achieve a better production (Barkema et al., 2015, Macciotta et al., 2017). In their study, carried out in cattle in order to define the best spot to measure the surface temperature, Stewart et al. (2010) concluded that the ocular temperature has a direct correlation with the variables pain and heat stress. Bartolomé et al. (2013) and George et al. (2014) revealed that the heat emitted by this area is related to changes in systemic blood flow and body temperature.

For cattle to express their full genetic potential, among other factors, the thermal environment must be within the thermal comfort zone. A new concept emerged with the modernization of animal husbandry called "precision livestock farming", which assists decision making, real-time monitoring and reduces losses (Putti et al., 2017a). In this context, the application of computer

\footnotetext{
${ }^{1}$ Universidade Federal do Vale do São Francisco/ Juazeiro - BA, Brasil.

${ }^{2}$ Universidade Federal de lavras/ Lavras - MG, Brasil.
}

Area Editor: Danilo Florentino Pereira

Received in: 4-1-2020

Accepted in: 5-16-2021 
modeling has been widely used, such as fuzzy logic and neural networks, both in agriculture (Rocha Neto et al., 2015, Putti et al, 2017a, Putti et al., 2017b,) and in the areas of animal comfort (Schiassi et al., 2015, Hernández Julio et al., 2015, Mirzaee-Ghalehv et al., 2015, Bahuti, et al., 2018, Lourençoni, et al., 2019a, Lourençoni, et al., 2019b, Abreu et al., 2020).

Fuzzy logic is a tool that can be used as an aid to decision making, for example providing control of the thermal environment within poultry facilities (Oliveira et al, 2018). The rule base, which relates the system's input variables with the output variables, is designed according to expert opinions, thus presenting a subjective aspect.

The process of exploring large amounts of data with fuzzy logic and neural networks has contributed to the advancement, speed and effectiveness of research in livestock production (Perissinotto et al., 2009, Hernández Julio et al., 2015, Morota et al., 2018). According to Brunassi et al. (2006), it was possible to have a satisfactory response when evaluating temperature and relative humidity in dairy cows, having as well-established criteria the animal thermal comfort, according to parameters of the fuzzy logic system.

Given the above, the present study aims to propose a fuzzy logic model capable of predicting ocular temperature (OT) by means of dry-bulb temperature (DBT) and relative humidity $(\mathrm{RH})$.

\section{MATERIAL AND METHODS}

The study was carried out in July 2016 at a commercial cattle production farm located in the south of the state of Minas Gerais. The climate classification of the region according to Köppen is Cwa, humid temperate climate, with dry season in winter and a hot summer (Peel et al., 2007).
In this experiment, 28 Brahman cattle (Bos Taurus Indicus) bred in extensive production systems (totally on pasture), were evaluated. For each animal, two thermal images of the entire head were collected using an infrared thermographic camera (Fluke Ti 55ft, Fluke Corporation, Everett, WA) with emissivity configured between 0.95 and 0.98 (Salles et al., 2016). The images were collected in the afternoon, with the animals in the shade, in a shed covered with asbestos cement tiles, height of $3 \mathrm{~m}$ and well ventilated, with ambient temperature varying from 29.1 to $31.2^{\circ} \mathrm{C}$ and relative humidity varying from 24.4 to $25.6 \%$. After the images were collected, they were analyzed using Fluke SmartView 3.0 software, which obtained responses from the animal's eye temperature (OT).

Concurrently with image collection, the meteorological variables, DBT and RH were collected utilizing a datalogger (Onset HOBO ${ }^{\circledR}$ TEMP/ RH/2 ext channels / accuracy of $\pm 3 \%$ of reading and accuracy of \pm $1{ }^{\circ} \mathrm{C}$ for temperature and $\pm 5 \%$ for relative humidity). The data were collected in the experimental area near the animals, at a height of $1.5 \mathrm{~m}$ from the ground at intervals of one minute. The animals remained in the experimental area during the entire testing period.

For the development of the fuzzy logic system, the Mandani inference method was used (Mandani, 1976), which presents as a response, a fuzzy set originated from the combination of the input values with their respective degrees of pertinence, through the minimum operator and then by the superposition of rules, through the maximum operator (Leite et al., 2010). The input variables were defined as DBT and RH being represented by trapezoidal pertinence curves (Figure 1), which were chosen because they better reproduce the data set (Schiassi et al., 2015) and using thermal comfort parameters for zebuin cattle determined by different authors (Tosetto et al., 2014; Moraes et al., 2020).
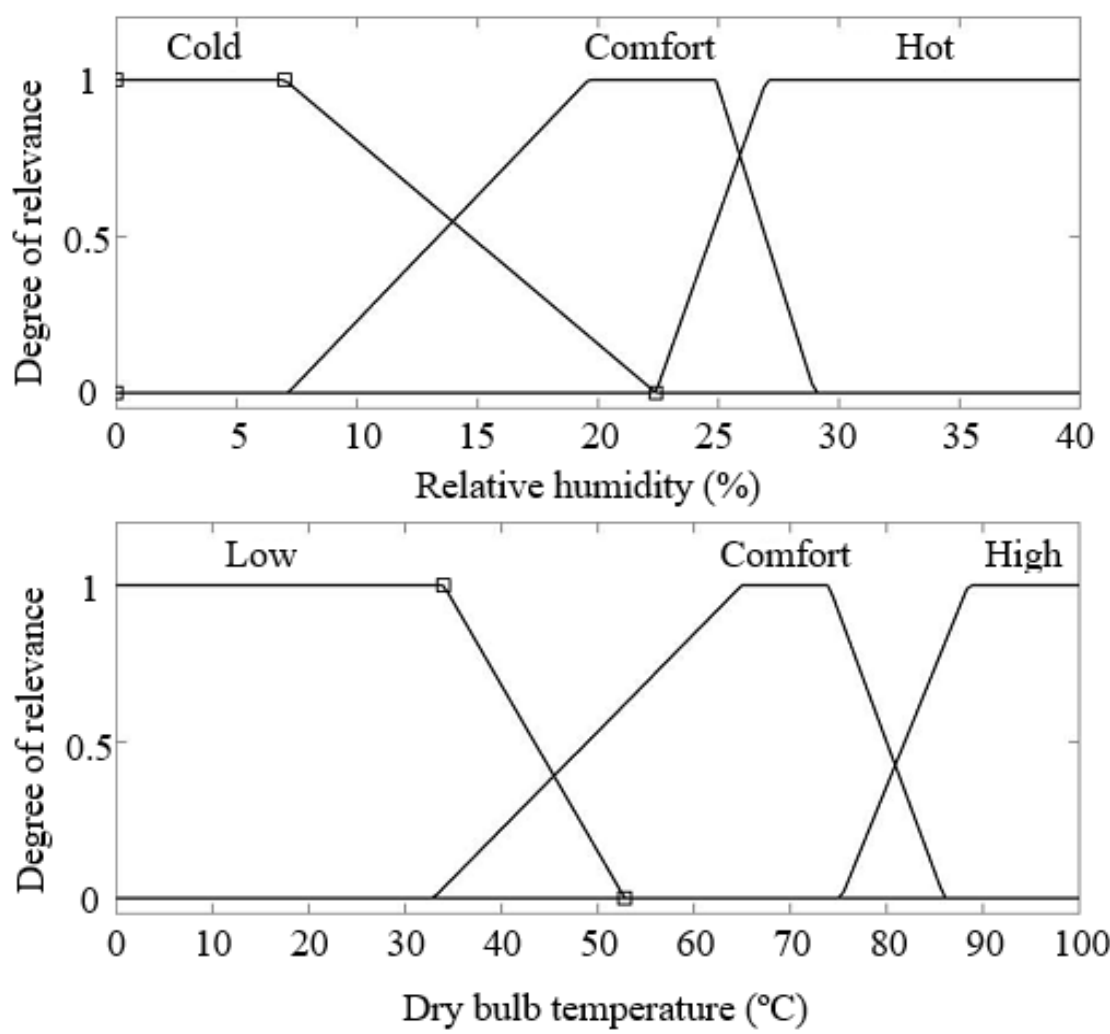

FIGURE 1. Pertinence functions for fuzzy logic model input variables, dry bulb temperature and relative air humidity. 
According to the combinations of DBT and RH (Figure 1), nine rules were defined (Table 1), in the form of language sentences based on the data collected and with the help of specialists. For the choice of experts, the methodology proposed by Cornelissen et al. (2002) was used, where four experts with more than ten years experience in animal environment and fuzzy logic modeling were selected to assist in assembling the rules. For each rule a weighting factor of 1 was assigned because in this study all rules have the same importance in determining the model responses. Based on the input variables and using as reference the experimental data, the fuzzy logic system predicts the variable OT, also characterized by trapezoidal type pertinence curves (Figure 2). The defuzzification was performed using the center of gravity method (Centroid or Area Center), which considers all output alternatives, converting the fuzzy set originated by the inference into numerical value (Leite et al., 2010, Schiassi et al., 2015).

TABLE 1. Fuzzy inference system rules considered for the input and output variables.

\begin{tabular}{|c|c|c|c|}
\hline \multirow{2}{*}{ Rule } & \multicolumn{2}{|c|}{ Input variables } & \multirow{2}{*}{$\begin{array}{c}\text { Output variable } \\
\text { Ocular temperature }\left({ }^{\circ} \mathrm{C}\right)\end{array}$} \\
\hline & dry-bulb temperature (DBT) & relative humidity $(\mathrm{RH})$ & \\
\hline 1 & Cold & Low & Low \\
\hline 2 & Cold & Comfort & Low \\
\hline 3 & Cold & High & Comfort \\
\hline 4 & Hot & Low & High \\
\hline 5 & Hot & Comfort & High \\
\hline 6 & Hot & High & High \\
\hline 7 & Comfort & Low & Comfort \\
\hline 8 & Comfort & Comfort & Comfort \\
\hline 9 & Comfort & High & Comfort \\
\hline
\end{tabular}

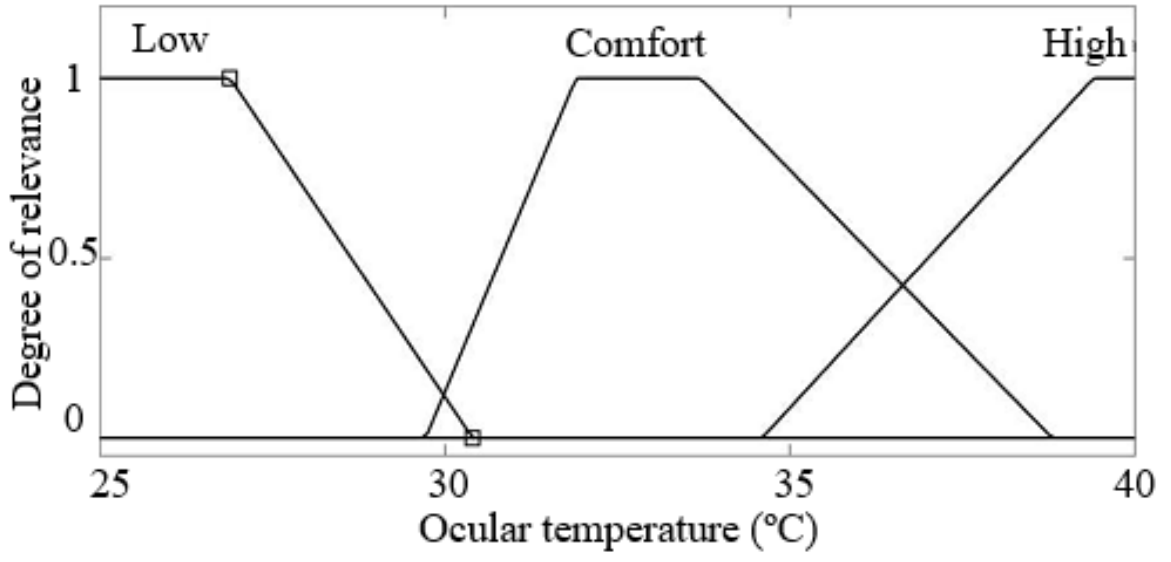

FIGURE 2. Pertinence functions for fuzzy model input variable, ocular temperature.

To perform the validation of the fuzzy logic system developed, the data measured by means of thermographic images were used. The development of the fuzzy logic system and the simulations were performed with the help of MATLAB ${ }^{\circledR}$ Fuzzy Toolbox $\AA$, software version 7.13.0.564 (R2011b). For evaluation of the proposed system, the simulated and observed ocular temperatures were compared using the standard deviation and the mean percentage error.

\section{RESULTS AND DISCUSSION}

The adjustment of the fuzzy logic model was performed based on the data collected in the experiment (Table 2), and the interval for each function of pertinence of the input and output variables was adopted to obtain the lowest possible error when compared with the experimentally measured data, which indicates the greatest relevance in decision making regarding the problem of thermal stress of animals. Perissinotto et al. (2009) used the same statement when evaluating the input variables, rectal temperature and respiratory rate, obtaining animal thermal comfort as a response. 
TABLE 2. Mean values and standard deviations (in brackets) of input variables, dry bulb temperature and relative humidity, and output variable, eye temperature, experimentally observed.

\begin{tabular}{|c|c|c|c|}
\hline \multirow{2}{*}{ Animal number } & \multicolumn{2}{|c|}{ Input variables } & \multirow{2}{*}{$\begin{array}{c}\text { Output variable } \\
\text { Ocular temperature }\left({ }^{\circ} \mathrm{C}\right)\end{array}$} \\
\hline & Dry-bulb temperature $\left({ }^{\circ} \mathrm{C}\right)$ & Relative Humidity (\%) & \\
\hline 1 & 32.3 & 50.4 & $30.3(1.17)$ \\
\hline 2 & 33.5 & 53.7 & $30.9(1.57)$ \\
\hline 3 & 33.8 & 49.9 & $31.4(1.24)$ \\
\hline 4 & 32.5 & 48.1 & $30.1(1.12)$ \\
\hline 5 & 32.6 & 49.2 & $30.3(1.52)$ \\
\hline 6 & 33.3 & 49.0 & $31.1(1.35)$ \\
\hline 7 & 33.0 & 49.0 & $30.5(1.56)$ \\
\hline 8 & 32.9 & 48.2 & $30.6(1.28)$ \\
\hline 9 & 33.1 & 45.9 & $31.0(1.30)$ \\
\hline 10 & 33.6 & 45.0 & $31.6(1.11)$ \\
\hline 11 & 34.1 & 42.8 & $32.1(0.95)$ \\
\hline 12 & 34.6 & 40.4 & $31.8(1.19)$ \\
\hline 13 & 35.1 & 35.0 & $32.6(1.06)$ \\
\hline 14 & 35.5 & 34.1 & $33.8(0.90)$ \\
\hline 15 & 35.9 & 33.2 & $33.4(1.03)$ \\
\hline 16 & 36.1 & 31.3 & $33.9(1.09)$ \\
\hline 17 & 36.9 & 27.8 & $35.3(0.87)$ \\
\hline 18 & 37.1 & 28.3 & $35.6(0.89)$ \\
\hline 19 & 37.3 & 28.0 & $35.7(0.89)$ \\
\hline 20 & 37.3 & 26.5 & $35.8(0.92)$ \\
\hline 21 & 37.4 & 24.1 & $35.8(0.93)$ \\
\hline 22 & 36.5 & 23.9 & $35.0(0.87)$ \\
\hline 23 & 37.3 & 23.6 & $36.1(0.66)$ \\
\hline 24 & 38.1 & 23.7 & $36.3(0.95)$ \\
\hline 25 & 39.7 & 23.8 & $38.5(0.66)$ \\
\hline 26 & 40.1 & 24.2 & $38.3(0.74)$ \\
\hline 27 & 40.3 & 25.4 & $38.8(0.77)$ \\
\hline 28 & 40.4 & 24.2 & $39.1(0.93)$ \\
\hline
\end{tabular}

Therefore, the values of OT simulated by the fuzzy logic system as a function of the DBT and RH were compared to the data obtained experimentally by means of the infrared thermographic camera (Table 3). It was observed that the fuzzy logic system predicted the OT of the animals, with a mean standard deviation of $0.5^{\circ} \mathrm{C}$ and a mean percentage error of $1.71 \%$ for modeling using data from DBT and RH from the external environment. 
TABLE 3. Comparison of the mean ocular temperature $\left({ }^{\circ} \mathrm{C}\right)$ as a function of dry-bulb temperature $\left({ }^{\circ} \mathrm{C}\right)$ and relative humidity $(\%)$, obtained experimentally and simulated by the fuzzy logic model.

\begin{tabular}{|c|c|c|c|c|}
\hline Animal number & Experimental data & Fuzzy simulation & Standard deviation & Percentage error $(\%)$ \\
\hline 1 & 32.3 & 32.0 & 0.1 & 0.6 \\
\hline 2 & 33.5 & 32.5 & 0.7 & 3.1 \\
\hline 3 & 33.8 & 32.7 & 0.7 & 3.0 \\
\hline 4 & 32.5 & 32.7 & 0.1 & 0.6 \\
\hline 5 & 32.6 & 32.7 & 0.1 & 0.3 \\
\hline 6 & 33.3 & 32.9 & 0.3 & 1.2 \\
\hline 7 & 33.0 & 32.9 & 0.1 & 0.4 \\
\hline 8 & 32.9 & 33.2 & 0.2 & 0.9 \\
\hline 9 & 33.1 & 33.5 & 0.3 & 1.5 \\
\hline 10 & 33.6 & 33.8 & 0.2 & 0.7 \\
\hline 11 & 34.1 & 34.1 & 0.0 & 0.0 \\
\hline 12 & 34.6 & 34.4 & 0.2 & 0.7 \\
\hline 13 & 35.1 & 34.8 & 0.2 & 0.8 \\
\hline 14 & 35.5 & 35.2 & 0.2 & 0.8 \\
\hline 15 & 35.9 & 35.6 & 0.2 & 0.7 \\
\hline 16 & 36.1 & 36.1 & 0.1 & 0.2 \\
\hline 17 & 36.9 & 37.6 & 0.5 & 1.9 \\
\hline 18 & 37.1 & 37.0 & 0.1 & 0.3 \\
\hline 19 & 37.3 & 37.6 & 0.2 & 0.9 \\
\hline 20 & 37.3 & 37.6 & 0.2 & 0.8 \\
\hline 21 & 37.4 & 38.2 & 0.6 & 2.3 \\
\hline 22 & 36.5 & 38.2 & 1.2 & 4.7 \\
\hline 23 & 37.3 & 38.2 & 0.6 & 2.5 \\
\hline 24 & 38.1 & 38.2 & 0.1 & 0.3 \\
\hline 25 & 39.7 & 38.2 & 1.0 & 3.7 \\
\hline 26 & 40.1 & 38.2 & 1.3 & 4.7 \\
\hline 27 & 40.3 & 38.2 & 1.5 & 5.2 \\
\hline \multirow[t]{2}{*}{28} & 40.4 & 38.2 & 1.5 & 5.3 \\
\hline & & Mean & 0.5 & 1.71 \\
\hline
\end{tabular}

In a study carried out by Schaefer et al. (2012), the efficiency found by the infrared thermography system was $93 \%$, indicating that the average temperature of the ocular orbits found in the animals of their study was $34.91{ }^{\circ} \mathrm{C}$ for healthy animals. As a comparison, in the present study the average observed value for all animals was $35.7^{\circ} \mathrm{C}$.

The results of this study corroborate the work of Brunassi et al. (2006), who demonstrated the efficiency of using fuzzy logic in the evaluation of estrus in cows, in which the producer will receive $98.3 \%$ certainty of the estrus of cows, thus conferring a high degree of reliability to the detection models available in the market.
According to the simple linear regression and with the adjustment of the line passing through the origin, the results show a determination coefficient $\mathrm{R}^{2}=0.8749$ (Figure 3), indicating good accuracy of the fuzzy logic model to predict the ocular temperature of the animals. The ocular temperature is an important index of animal welfare (Stewart et al., 2010). According to Stewart et al. (2005), the infrared temperature of the eye can detect changes in peripheral blood flow, thus being a useful index to assess stress in these animals. It is noteworthy that the thermal tolerance varies considerably with the herd, breed and individual. (Silanikove, 2000, Van Laer et al., 2014). 


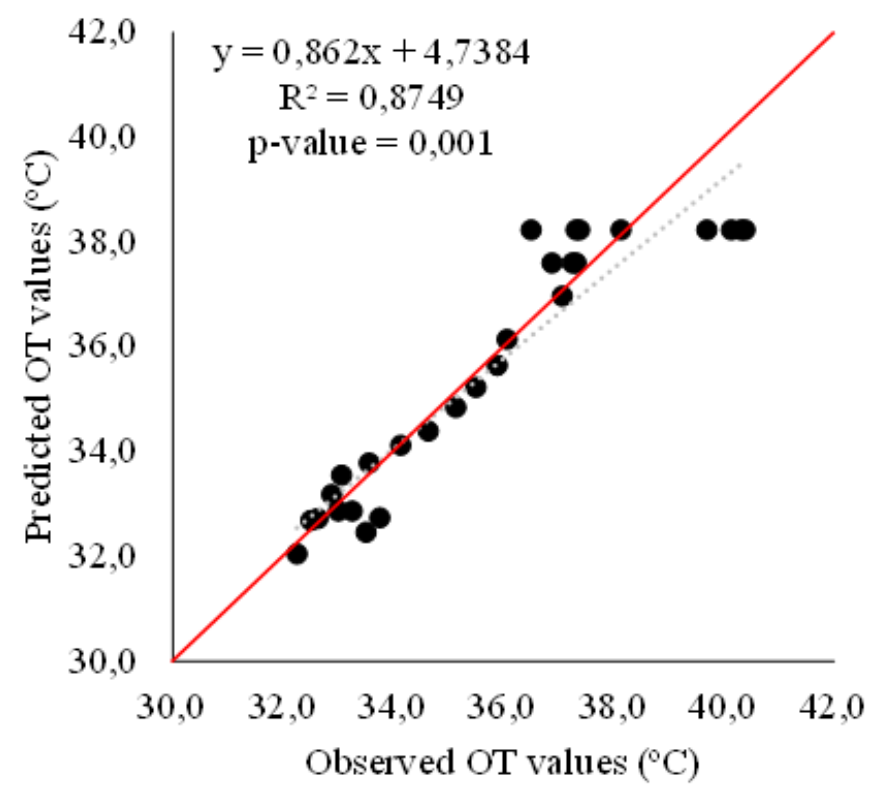

FIGURE 3. Linear regression for the ocular temperature output variable as a function of the values estimated by the fuzzy model and the values measured experimentally.

In Figure 4, it can be seen that the values of the OT follow the values of the DBT, i.e., the increases in environmental temperature are directly related to heat production and increased blood flow, which can be assessed by ocular thermography (Bartolomé et al., 2013, Church et al., 2014, George et al., 2014). Thus, the OT values increase with the increase in DBT, and as DBT increases, the difference between OT and DBT decreases.

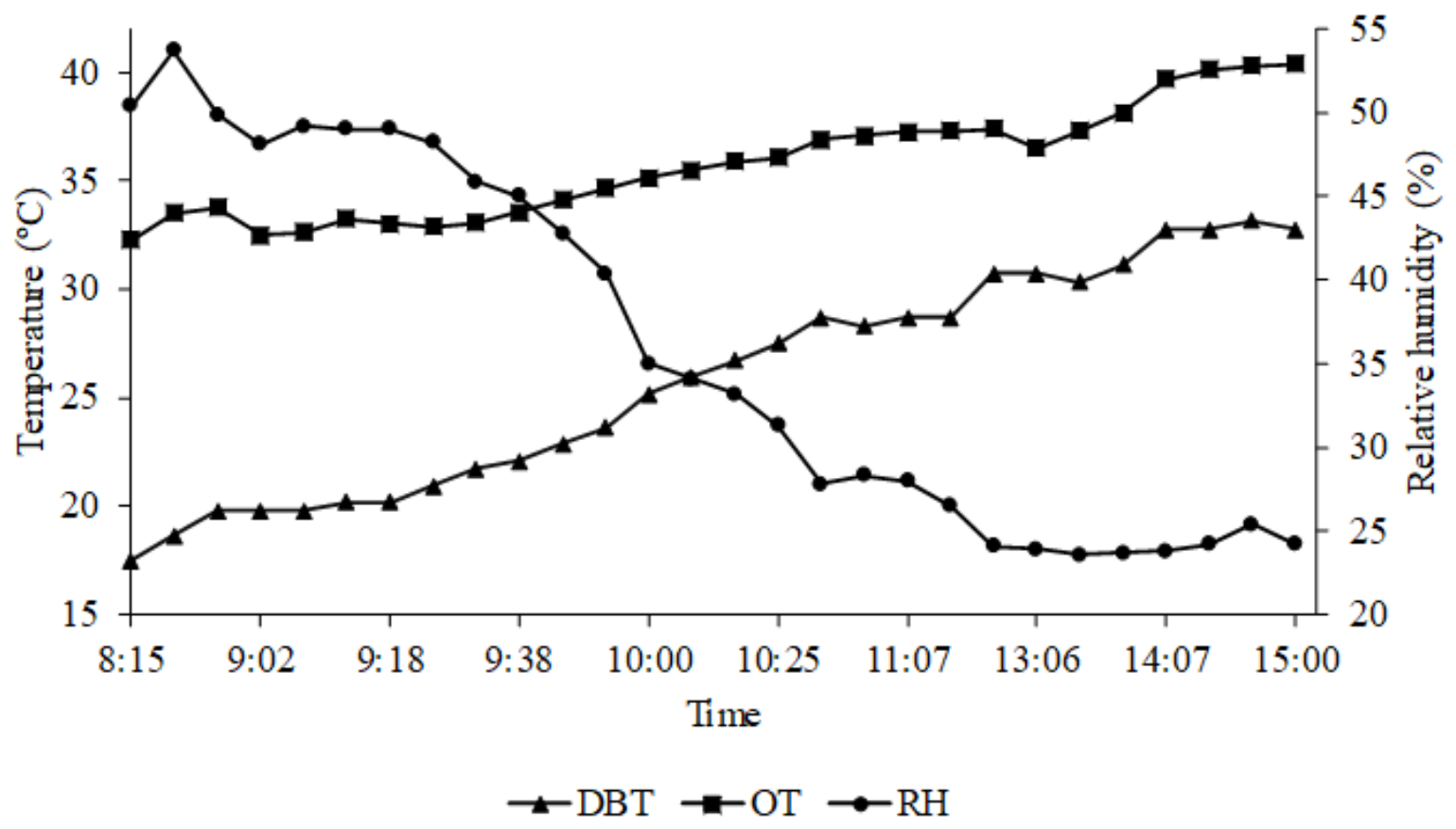

FIGURE 4. Graphs with the input variables dry-bulb temperature (DBT), relative humidity (RH) and the output variable eye temperature (OT) collected experimentally.

It should be highlighted that most of the Brazilian territory is in the tropical range with high incidence of solar radiation, with average temperatures above $20^{\circ} \mathrm{C}$ and maximums above $30^{\circ} \mathrm{C}$ (Rezende et al., 2015), leaving the bovine herd vulnerable to heat stress (Mollo Neto \& Nääs, 2014), especially cattle raised in a vast grazing system (Pinheiro et al., 2015). In this context, new non-invasive methodologies, such as infrared thermography and fuzzy logic, may assist in the classification of the thermal comfort status of these animals, helping management make decisions for better animal welfare.

\section{CONCLUSIONS}

The proposed fuzzy logic model allows to accurately estimate the ocular temperature of grazing beef cattle, helping in the decision making for better animal welfare. 


\section{ACKNOWLEDGEMENTS}

The authors express their acknowledgments to FAPEMIG, CAPES and CNPq for their support to this research.

\section{REFERENCES}

Abreu LHP, Yanagi Junior T, Bahuti M, Hernández-Julio YF, Ferraz PFP (2020) Artificial neural networks for prediction of physiological and productive variables of broilers. Engenharia Agrícola 40(1): 1-9. DOI: https://doi.org/10.1590/1809-4430

Barkema HW, Von Keyserlingk MA, Kastelic JP, Lam TJ, Luby C, Roy JP, Leblanc SJ, Keefe GP, Kelton DF (2015) Invited review: Changes in the dairy industry affecting dairy cattle health and welfare. Journal of Dairy Science 98(11):7426-7445. DOI: https://doi.org/10.3168/jds.20159377

Bartolomé E, Sánchez MJ, Molina A, Schaefer AL, Cervantes I, Valera M (2013) Using eye temperature and heart rate for stress assessment in young horses competing in jumping competitions and its possible influence on sport performance animal. The Animal Consortium 7(12):20442053. DOI: https://doi.org/10.1017/S1751731113001626.

Bahuti M, Abreu LHP, Yanagi Junior T, Lima RR, Campos AT (2018) desempenho de sistemas de inferência fuzzy para prever a temperatura de superfície de frangos de frango. Engenharia Agrícola 38(6): 813-823. DOI: https://doi.org/10.1590/1809-4430-eng.agric.v38n6p813$823 / 2018$

Borchers MR, Chang YM, Proudfoot KL, Wadsworth BA, Stone AE, Bewley JM (2017) Machine-learning-based calving prediction from activity, lying, and ruminating behaviors in dairy cattle. Journal of Dairy Science 100(7): 5664-5674. DOI: https://doi.org/10.3168/jds.2016-11526

Brunassi L, Moura D, Nääs I (2006) Teste de um sistema fuzzy de identificação de estro em uma fazenda comercial de vacas leiteiras. In: simpósio de construções rurais e ambientes protegidos, SIMCRA 2006, Campinas, FEAGRI/UNICAMP.

Bustos Mac-Lean PA (2012) Program of supplementary light and the relationship between physiological and thermography variables of suckling calves in hot weather. Pirassununga, Universidade de São Paulo, Faculdade de Zootecnia e Engenharia de Alimentos.

DOI: https://doi.org/10.11606/T.74.2012.tde-0407201211421

Church JS, Hegadoren PR, Paetkau MJ, Miller CC, RegevShoshani G, Schaefer AL. Schwartzkopf-Genswein KS (2014) Influence of environmental factors on infrared eye temperature measurements in cattle. Research in Veterinary Science 96(1):220-226. DOI: https://doi.org/10.1016/j.rvsc.2013.11.006.

Cornelissen AMG, Van Den Berg J, Koops WJ, Kaymak U (2002) Elicitation of expert knowledge for fuzzy evaluation of agricultural production systems. Agriculture, ecosystems \& environment 95(1):1-18. DOI: https://doi.org/10.1016/S0167-8809(02)00174-3
Costa CCM, Maia ASC, Brown-Brandl TM, Neto MC, Fonsêca VDFC (2018) Thermal equilibrium of Nellore cattle in tropical conditions: an investigation of circadian pattern. Journal of thermal biology, 74:317-324. DOI: https://doi.org/10.1016/j.jtherbio.2018.04.014

Fonsêca VFC, Saraiva EP, Pimenta Filho EC, Furtado DA, Mariz TMA, Silva AL, Pinheiro AC (2014) Influence of the climatic environment and duration of labor on the mother-offspring interaction in Morada Nova sheep. Journal of Animal Science 92(9):4123-4129. DOI: https://doi.org/10.2527/jas.2014-7322.

Gabriel Filho LRA, Putti FF, Cremasco CP, Bordin D, Chacur MGM (2016) Software to assess beef cattle body mass through the fuzzy body mass index. Engenharia Agrícola. 36 (1): 179-193. DOI:

https://doi.org/10.1590/1809-4430-Eng.Agric.v36n1p179193/2016.

George WD, Godfrey RW, Ketring RC, Vinson MC, Willard ST (2014) Relationship among eye and muzzle temperatures measured using digital infrared thermal imaging and vaginal and rectal temperatures in hair sheep and cattle. Journal of Animal Science, 92:4949-4955. DOI: https://doi.org/10.2527/jas.2014-8087.

Gorczyca MT, Milan HFM, Maia ASC, Gebremedhin KG (2018) Machine learning algorithms to predict core, skin, and hair-coat temperatures of piglets. Computers and Electronics in Agriculture, 151:286-294. DOI: https://doi.org/10.1016/j.compag.2018.06.028

Hernández Julio YF, Yanagi Junior T, Pires MFA, Lopes MA, Lima RR (2015) Fuzzy system to predict physiological responses of Holstein cows in southeastern Brazil. Rev Colombiana de Ciencias Pecuarias 28(1):4253. ISSN 0120-0690.

Kokin E, Praks J, Veermäe I, Poikalainen V, Vallas M (2014) IceTag3 $\mathrm{D}^{\mathrm{TM}}$ accelerometric device in cattle lameness detection. Agronomy Research 12(1):223-230.

Leite MS, Fileti AMF, Silva FV (2010) Development and experimental application of fuzzy and conventional controllers in a bioprocess. Control \& Automation 21(2):147-158. DOI: https://doi.org/10.1590/S010317592010000200004

Lourençoni D, Yanagi Junior T, Yanagi SNM, Abreu PG, Campos AT (2019a) Respostas produtivas de frangos de frango criados em diferentes sistemas de produção comercial - Parte I: Impacto das mudanças climáticas. Engenharia Agrícola 39(1): 1-10. DOI:

https://doi.org/10.1590/1809-4430-eng.agric.v39n1p1$10 / 2019$

Lourençoni D, Yanagi Junior T, Yanagi SNM, Abreu PG, Campos AT (2019b) Respostas produtivas de frangos de frango criados em diferentes sistemas de produção comercial - Parte II: Impacto das mudanças climáticas. Engenharia Agrícola 39(1): 11-17. DOI: https://doi.org/10.1590/1809-4430-eng.agric.v39n1p11$17 / 2019$ 
Macciotta NPP, Biffani S, Bernabucci U, Lacetera N, Vitali A, Ajmone-Marsan P, Nardone A (2017) Derivation and genome-wide association study of a principal component-based measure of heat tolerance in dairy cattle. Journal of Dairy Science 100(6):4683-4697.

Maia ASC, da Silva RG, Nascimento ST, Nascimento CCN, Pedroza HP, Domingos HGT (2015)

Thermoregulatory responses of goats in hot environments. International journal of biometeorology 59(8):1025-1033. DOI: https://doi.org/10.1007/s00484-014-0916-3.

Mandani EH (1976) Advances in the linguistic syntesis of fuzzy controllers. International Journal of Man-Machine Studies 8(6):669-678. DOI: https://doi.org/10.1016/S00207373(76)80028-4.

Milan HFM, Maia ASC, Gebremedhin KG (2016) Technical note: Device for measuring respiration rate of cattle under field conditions. Journal of Animal Science 94(12):5434-5438. DOI: https://doi.org/10.2527/jas.20160904.

Mollo Neto M, Nääs IA (2014) Pecision farming software to monitor environmental parameters of thermal comfort in dairy farming. Brazilian Journal of Biosystems Engineering 8(2):112-127. DOI: https://doi.org/10.18011/bioeng2014v8n2p112-127.

Moraes ER., Ishihara JH., Sales DE (2020) Efeito do bemestar e conforto térmico na produção pecuária: uma revisão bibliográfica. Research, Society and Development 9(9): e921997913-e921997913

Morota G, Ventura RV, Silva FF, Koyama M, Fernando S C (2018) Machine learning and data mining advance predictive big data analysis in precision animal agriculture. Journal of Animal Science 96(4):1540-1550. DOI: https://doi.org/10.1093/jas/sky014.

Moura DJD, Maia APDA, Vercellino RDA, Medeiros BB, Sarubbi J, Griska PR (2011) Use of infrared thermography in the analysis of horse thermoregulation in training. Agricultural Engineering 31(1):23-32. DOI: https://doi.org/10.1590/S0100-69162011000100003

Nascimento ST, Maia AS, Gebremedhin KG, Nascimento CC (2017) Metabolic heat production and evaporation of poultry. Poultry Science 96(8):2691-2698. DOI: https://doi.org/10.3382/ps/pex094.

Oliveira RF, Ferreira RA, Abreu LHP, Yanagi Júnior T, Lourençoni D (2018) Estimation of respiratory frequency and rectal temperature on pigs in heat stress by fuzzy logic. Engenharia Agrícola 38: 457-470. DOI: https://doi.org/10.1590/1809-4430-eng.agric.v38n4p457$470 / 2018$

Peel MC, Finlayson BL, McMahon TA (2007) Updated world map of the Köppen-Geiger climate classification. Hydrology and Earth System Sciences Discussions 4(2):439-473. DOI: https://doi.org/10.5194/hess-11-1633-2007.

Perissinotto M, Moura DJ, Cruz VF, Souza SRLD, Lima KAOD, Mendes AS (2009) Thermal comfort of dairy cattle confined in subtropical and Mediterranean climate by analysis of physiological parameters using fuzzy set theory. Rural science, 39(5):1492-1498. DOI: https://doi.org/10.1590/S0103-84782009005000094.
Pinheiro AC, Saraiva EP, Saraiva CAS, Fonseca VDFC, Almeida MEV, Santos SGGC, Amorim MLCM, Rodrigues Neto PJ (2015) Anatomo-physiological characteristics of adaptation of dairy cattle to the tropical environment. Technical Agriculture 36(1):280-293. ISSN 0100-7467

Putti FF, Kummer ACB, Grassi Filho H, Gabriel Filho LRA, Cremasco CP (2017a) modelagem fuzzy sobre a produtividade de trigo em diferentes doses de lodo e efluente de esgoto. Engenharia Agrícola, 37(6): 11031115. DOI: https://doi.org/10.1590/1809-4430eng.agric.v37n6p1103-1115/2017

Putti FF, Gabriel Filho LRA, Gabriel CPC, Bonini Neto A, Bonini CSB, Reis AR (2017b) A Fuzzy mathematical model to estimate the effects of global warming on the vitality of Laelia purpurata orchids. Mathematical

Biosciences 288:124-129. DOI:

https://doi.org/10.1016/j.mbs.2017.03.005

Rezende SR, Munhoz SK, Nascimento MRBM, Guimarães JLN (2015) Thermoregulation characteristics in dairy cows in tropical environment: review. Veterinary News 21(1):18-29. DOI: https://doi.org/10.14393/VTv21n1a2015.24709

Rocha Neto OC, Teixeira AS, Braga APS, Santos CC, Leão RAO (2015) Application of artificial neural networks as an alternative to volumetric water balance in drip irrigation management in watermelon crop. Engenharia Agrícola 35(2):266-279. DOI:

https://doi.org/10.1590/1809-4430-Eng.Agric.v35n2p266$279 / 2015$

Salles MSV, da Silva SC, Salles FA, Roma Jr LC, El Faro L, Mac Lean PAB, Martello LS (2016) Mapping the body surface temperature of cattle by infrared thermography. Journal of Thermal Biology 62:63-69. DOI: https://doi.org/10.1016/j.jtherbio.2016.10.003.

Schaefer AL, Cook NJ, Bench C, Chabot JB, Colyn J, Liu T, Webster JR (2012) The non-invasive and automated detection of bovine respiratory disease onset in receiver calves using infrared thermography. Research in Veterinary Science 93(2):928-935. DOI: https://doi.org/10.1016/j.rvsc.2011.09.021.

Schiassi L, Yanagi Júnior T, Reis GM, Abreu LHP, Campos AT, Castro JO (2015) Modelagem fuzzy aplicada a avaliação do desempenho dos frangos de corte. Revista Brasileira de Engenharia Agrícola e Ambiental, Campina Grande 19: 140-160. DOI: https://doi.org/10.1590/18071929/agriambi.v19n2p140-146

Silanikove N (2000) Effects of heat stress on the welfare of extensively managed domestic ruminants. Liverstock Production Science 67(1):1-18. DOI: 10.1016/S03016226(00)00162-7.

Stewart M, Webster JR, Schaefer AL, Cook NJ, Scott SL (2005) Infrared thermography as a non-invasive tool to study animal welfare. Animal Welfare 14(4):319-325. 
Stewart M, Stafford KJ, Dowling SK, Schaefer AL, Webster JR (2008) Eye temperature and heart rate variability of calves disbudded with or without local anaesthetic. Physiology \& Behavior 93(4-5):789-797. DOI: https://doi.org/10.1016/j.physbeh.2007.11.044.

Stewart M, Webster JR, Stafford KJ, Schaefer AL, Verkerk GA (2010) Effects of an epinephrine infusion on eye temperature and heart rate variability in bull calves. Journal of dairy science 93(11):5252-5257. DOI: https://doi.org/10.3168/jds.2010-3448.
Tosetto MR, Maia APA, Sarubbi J, Zancanaro BMD, Lima CZ, Sippert MR (2014) Influência do macroclima e do microclima sobre conforto térmico de vacas leiteiras. Journal of Animal Behaviour and Biometerology 2:6-10. DOI: https://doi.org/10.14269/2318-1265.v02n01a02

Van Laer E, Moons CPH, Sonck B, Tuyttens FAM (2014) Importance of outdoor shelter for cattle in temperate climates. Livestock Science 159: 87-101. DOI: https://doi.org/10.1016/j.livsci.2013.11.003 